\title{
Influence of different types of commercially available microcrystalline cellulose on degradation of perindopril erbumine and enalapril maleate in binary mixtures
}

\author{
TANJA VEHOVEC ${ }^{1}$ \\ ANDREJ GARTNER ${ }^{1}$ \\ ODON PLANINŠEK ${ }^{2}$ \\ ALEŠ OBREZA ${ }^{*}$ \\ ${ }^{1}$ Krka d.d. Novo mesto, Stability \\ Testing Department, 8501 Novo mesto \\ Slovenia \\ 2 University of Ljubljana, Faculty of \\ Pharmacy, 1000 Ljubljana, Slovenia
}

\begin{abstract}
Influence of some commercially available types of microcrystalline cellulose (MCC) on the stability of certain active pharmaceutical ingredients (APIs), when in contact, has been investigated. Two structurally similar APIs, perindopril erbumine (PER) and enalapril maleate (EM), both well-known angiotensin-converting enzyme inhibitors were used. The main properties of an MCC that could determine the stability for each API were measured and correlated to the stability of these two APIs in binary mixtures. The stability of these APIs differed when in contact with different types of MCC. The dominant properties of MCC from one manufacturer were surface features that influenced the stability of PER and acidity that influenced the stability of EM. In the case of MCC from other manufacturers, unbound water was stability determining for both substances.
\end{abstract}

Keywords: microcrystalline cellulose, perindopril erbumine, enalapril maleate, stability study, drug-excipient binary mixtures

Numerous types of microcrystalline cellulose (MCC) are available on the market for a variety of uses in pharmaceutical industry. They can be used as adsorbents, anti-adherents, binders/diluents and tablet disintegrants (1). On the industrial scale, MCC is obtained by hydrolysis of wood and cotton cellulose using dilute mineral acids. The treated pulp is then rinsed and spray-dried with or without an additional process step such as milling. Cellulose from different sources differs in the properties such as crystallinity, moisture content, surface area, porous structure, molecular mass. These properties can be also affected by the conditions of hydrolysis. Preparations of MCC from materials other than wood and cotton (e.g., water hyacinth, coconut shells, wheat and rice straws, etc.) have also been reported (2).

\footnotetext{
* Correspondence; e-mail: Ales.Obreza@ffa.uni-lj.si
} 
T. Vehovec et al.: Influence of different types of commercially available microcrystalline cellulose on degradation of perindopril erbumine and enalapril maleate in binary mixtures, Acta Pharm. 62 (2012) 515-528.

MCC (Fig. 1) is a partially depolymerized cellulose and is composed of crystalline and amorphous domains. The relatively large surface to volume ratio of micro fibrils, due to their small size, and the presence of abundant hydroxyl groups makes MMC hygroscopic (3). An important property of MCC as an excipient is its moisture content, which should not exceed $7.0 \%(\mathrm{~m} / \mathrm{m})$ according to the European Pharmacopoeia (4). Hygroscopicity is one of the main limitations to using MCC in pharmaceutical formulations, since it may induce instability of moisture-sensitive drugs (5). MCC has been referred to as a "molecular sponge", because most of the water held by MCC is present as free water that may be readily lost by evaporation (6). It should be noted that moisture content itself says little about an excipient's propensity to promote hydrolysis. It has been shown that while cellulose powders with a lower degree of crystallinity contain more water than their counterparts with a higher degree $(7,8)$, the former exhibit lower rates of degradation of acetylsalicylic acid than the latter (9). The study of the influence of water-binding energy of cellulose on the stability of acetylsalicylic acid revealed that each water molecule formed on average more hydrogen bonds in low-crystallinity cellulose (LCC) than in ordinary MCC and in high-crystallinity cellulose (HCC). Therefore, the stability of acetylsalicylic acid was greater in a binary mixture with LCC, since despite a larger amount of total water content, fewer water molecules were available to induce hydrolysis (10).

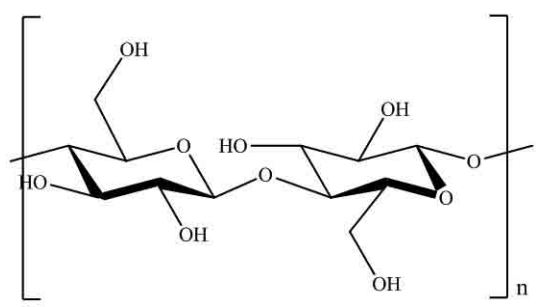

Fig. 1. Structular formula of cellulose.

Perindopril erbumin (PER, Fig. 2a) and enalapril maleate (EM, Fig. 2b) are angiotensin-converting enzyme inhibitors (ACE inhibitors), used in the treatment of hypertension. According to the European Pharmacopoeia and published papers (4, 11-13), the main degradation pathways of PER and EM in solution and in solid state are ester hydrolysis and intramolecular cyclization, respectively, with first-order kinetics with respect to substrate concentration (13-15). While, for hydrolysis, increased relative humidity of the environment plays a major role, the formation of the cyclic product diketopiperazine (DKP) is accelerated at elevated temperature and in an acidic environment. EM is very stable when stored at room temperature (amber glass) for 4 years it showed no evidence of degradation as determined by HPLC analysis (16). PER is less stable. The mechanisms and rates of degradation of both ACE-inhibitors are highly $\mathrm{pH}$ dependent, both substances being quite stable in neutral and acidic environments (13).

The different types of MCC, according to manufacturers and also in a monograph of MCC with functionality-related characteristics (FRC) in European Pharmacopoeia (4), 
T. Vehovec et al:: Influence of different types of commercially available microcrystalline cellulose on degradation of perindopril erbumine and enalapril maleate in binary mixtures, Acta Pharm. 62 (2012) 515-528.

are characterized mainly from the technological and not from the stability point of view. The aim of this study was to investigate the influence of different commercially available types of MCC on the stability of an API when the two are in contact, since the choice of suitable excipients is one of the most important steps in drug formulation and influences the stability of the final product. Therefore, also those physicochemical properties of MCCs which are most important in correlating to stability of these two APIs in binary mixtures were identified and evaluated.

a)

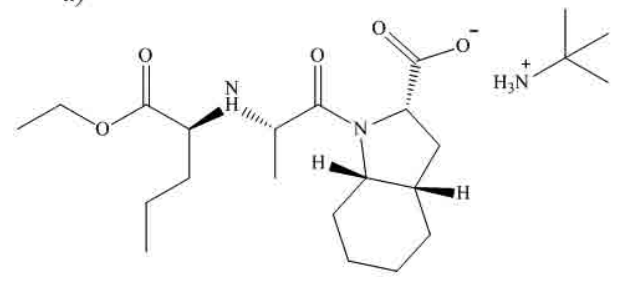

b)<smiles>CCOC(=O)[C@H](CCc1ccccc1)N[C@@H](C)C(=O)N1CCC[C@H]1C(=O)O</smiles>

Fig. 2. Molecular structures of: a) perindopril erbumine and b) enalapril maleate.

\section{EXPERIMENTAL}

\section{Materials}

The different types of microcrystalline cellulose used in binary mixtures with APIs were obtained from three different manufacturers. They are compiled in Table I with important physicochemical properties according to the manufacturers.

For particle size and specific surface area determination of MCCs, ethanol, obtained from J. T. Baker (The Netherlands), was used as dispersion medium.

Probes used for the inverse gas chromatography (IGC) measurements of MCCs were non-polar alkanes, from hexane to decane (Fluka, Switzerland), and polar tetrahydrofuran, acetone, trichloromethane and ethyl acetate obtained from Sigma-Aldrich Chemie (Switzerland). Methane (Messer, Slovenia) was used as a non-adsorbing probe.

Perindopril erbumin and enalapril maleate, produced by Krka, d.d. (Slovenia) were used as APIs.

The following reagents were used for HPLC analysis of PER and its degradation products: acetonitrile (HPLC grade), $\mathrm{HClO}_{4}$ (p.a.), obtained from J. T. Baker, sodium heptanesulphonate $\left(\mathrm{C}_{7} \mathrm{H}_{15} \mathrm{NaO}_{3} \mathrm{~S}\right)$ (p.a.) from Merck (Germany), triethylamine (p.a.) from Sigma-Aldrich Chemie. The buffer solution of sodium heptanesulphonate with triethylamine was prepared in a concentration of $0.92 \mathrm{mg} \mathrm{mL}^{-1}$, which was adjusted with perchloric acid to $\mathrm{pH} 2.0$.

For HPLC analysis of EM and its degradation products, the following reagents were used: acetonitrile (HPLC grade), $\mathrm{H}_{3} \mathrm{PO}_{4}$ (p.a.) obtained from J. T. Baker, $\mathrm{KH}_{2} \mathrm{PO}_{4}$ (p.a.) 
T. Vehovec et al.: Influence of different types of commercially available microcrystalline cellulose on degradation of perindopril erbumine and enalapril maleate in binary mixtures, Acta Pharm. 62 (2012) 515-528.

Table I. Physicochemical properties of MCC powders according to the manufacturer

\begin{tabular}{lcccc}
\hline Type of MCC & $\begin{array}{c}\text { Particle } \\
\text { size }(\mu \mathrm{m})\end{array}$ & $\begin{array}{c}\text { Moisture } \\
\text { content }(\%)\end{array}$ & $\begin{array}{c}\text { Loose bulk } \\
\text { density }\left(\mathrm{g} \mathrm{cm}^{-3}\right)\end{array}$ & Manufacturer \\
\hline Avicel PH-101 $^{\text {a }}$ & 50 & 3.0 to 5.0 & $0.26-0.31$ & FMC, Ireland \\
Avicel PH-101 $^{\text {b }}$ & 50 & 3.0 to 5.0 & $0.26-0.31$ & \\
Avicel PH-101 $^{\text {c }}$ & 50 & 3.0 to 5.0 & $0.26-0.31$ & \\
Avicel PH-102 & 100 & 3.0 to 5.0 & $0.28-0.33$ & \\
Avicel PH-105 & 20 & $\leq 5.0$ & $0.20-0.30$ & \\
Avicel PH-112 & 100 & $\leq 1.5$ & $0.28-0.34$ & \\
Avicel PH-200 & 180 & 2.0 to 5.0 & $0.29-0.36$ & \\
Avicel PH-200 LM & 180 & $\leq 1.5$ & $0.30-0.38$ & Blanver, Brazil \\
Microcel MC-102 & 100 & max. $7 \%$ & $0.28-0.33$ & \\
Microcel MC-250 & 230 & max. $7 \%$ & $0.33-0.40$ & \\
Microcel MC-200 & 180 & max. $7 \%$ & $0.33-0.40$ & JRS Pharma, \\
Vivapur 102 & 100 & NI & $0.28-0.33$ & Germany \\
Vivapur 101 & 65 & NI & $0.26-0.31$ & \\
Vivapur 12 & 180 & NI & $0.30-0.36$ & \\
Emcocel LP200 & 190 & NI & $0.25-0.37$ & \\
\hline
\end{tabular}

a-c Different batches of the same type of MCC; NI - no information.

from Merck (Germany). The buffer solution of $\mathrm{KH}_{2} \mathrm{PO}_{4}$ was prepared in a concentration of $0.136 \mathrm{mg} \mathrm{mL}^{-1}$, which was adjusted with $\mathrm{H}_{3} \mathrm{PO}_{4}$ to $\mathrm{pH} 2.0$.

\section{Determination of acidity and moisture of microcrystalline cellulose}

Acidity and moisture content of MCCs were determined according to the monograph of MCC in European Pharmacopoeia (4). The $\mathrm{pH}$ was measured with a $\mathrm{pH}$ meter (Seven Multi, Mettler Toledo, Switzerland). Moisture content - loss on drying (LOD) was determined with an oven (SP-105 C, Kambič, Slovenia) in triplicate.

\section{Determination of particle size and specific surface area of microcrystalline cellulose}

Particle size of the different types of MCC was determined by laser light scattering (Mastersizer S, Malvern, UK) with a 300RF lens with a QS small volume sample dispersion unit for measuring liquid dispersion. Specific surface area (SSA) was calculated automatically by the laser diffraction system software from the equation, based on the assumption that the particles were perfectly smooth, solid spheres:

$$
S S A=\left(6 \Sigma\left(V_{\mathrm{i}} / d_{\mathrm{i}}\right)\right) /\left(\rho \Sigma V_{\mathrm{i}}\right)=6 /(\rho D[3.2])
$$

where $V_{\mathrm{i}}$ is the relative volume in class $i$ with a mean class diameter of $d_{\mathrm{i}}, \rho$ is the density of the material, and $D[3.2]$ is the surface area weighted mean diameter (18). 
T. Vehovec et al:: Influence of different types of commercially available microcrystalline cellulose on degradation of perindopril erbumine and enalapril maleate in binary mixtures, Acta Pharm. 62 (2012) 515-528.

\section{Inverse gas chromatography}

For the IGC analysis of MCCs, a commercial gas chromatograph (HP 5890A, Series II, Hewlett-Packard, USA) equipped with the flame ionization detector (FID) and ChemStation software was used. Dry helium (Messer, Slovenia) was used as carrier gas with a flow-rate of $7 \mathrm{~mL} \mathrm{~min}{ }^{-1}$. Glass columns $(0.2 \mathrm{~m}$ long and $3.0 \mathrm{~mm}$ i.d.) were packed by tapping the powder for $10 \mathrm{~min}$ in a tap density tester (VanKel, Cary, USA). Prior to measurements, filled columns were conditioned overnight with helium at a constant flow of

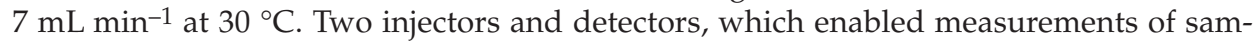
ples simultaneously, were heated at 150 (injectors) and $250{ }^{\circ} \mathrm{C}$ (detectors). Samples of MCC were analyzed at $30^{\circ} \mathrm{C}$. The probes, described under Materials, were injected automatically from a $10.0 \mu \mathrm{L}$ Hamilton syringe using an Agilent Technologies (USA) 7683 series auto injector.

The dispersive component of total surface free energy of the solid phase $\left(\gamma_{s}^{d}\right)$ and polar characteristics of the surface $\left(K_{\mathrm{a}}, K_{\mathrm{b}}\right)$ were calculated from the retention times of the probes measured at a series of concentrations and extrapolated to infinite dilution. The theoretical background of the IGC method is described in the literature (19-21).

\section{Water vapour sorption of microcrystalline cellulose}

A dynamic vapour sorption (DVS) method (DVS-1, Surface Measurement Systems Ltd., UK) was used to determine MCC water sorption. The analyses were performed at controlled room temperature $\left(25^{\circ} \mathrm{C}\right)$. A powder sample of about $14 \mathrm{mg}$ was dried to a stable weight on a balance by a stream of dry nitrogen gas at a rate of $200 \mathrm{~mL} \mathrm{~min}^{-1}$. The sample was then subjected to a series of relative humidities from 0 to $90 \%$ and back in 9 steps each way. Relative humidity (RH) from 0 to $90 \%$ is controlled through a DVS-1 instrument. No special chemicals were used, except water and $\mathrm{N}_{2}$. Equilibrium was assumed to be achieved when there was $<0.002 \% \mathrm{~min}^{-1}$ mass increase under the given relative humidity. One complete cycle for each sample of MCC was performed.

\section{Stability study of PER or EM alone and in binary mixtures with different types of MCC}

In the stability study, different types of MCC powders from three different manufacturers (FMC, Blanver, Brazil and JRS Pharma, Germany) and three different batches of the same type of one MCC, Avicel PH-101, were used. Individual mixtures of PER or EM with each MCC were prepared by mixing the constituents for 10 minutes. Mixtures of $12 \mathrm{~g}$ were prepared in 1:5 $(\mathrm{m} / \mathrm{m})$ ratio of PER or EM to MCC.

Each API/MCC mixture was divided into two equal parts. One part was placed in an open Petri dish and the other was filled into an HPLC vial (cca $700 \mathrm{mg}$ of mixture per vial), which was then closed. These two samples are referred to throughout the paper as being under 'open' and 'closed' conditions. Samples were stored in a climatic chamber (KK-1000, Kambič, Slovenia) at $40 \pm 2{ }^{\circ} \mathrm{C}$ and $75 \pm 5 \%$ RH. Samples were withdrawn at different time points (Table II). At each time point, two vials of each binary mixture and about $800 \mathrm{mg}$ of each binary mixture were withdrawn from the Petri dish. Accurately weighed samples, of about $360 \mathrm{mg}$, of mixtures with PER and of about $120 \mathrm{mg}$ of mix- 
T. Vehovec et al.: Influence of different types of commercially available microcrystalline cellulose on degradation of perindopril erbumine and enalapril maleate in binary mixtures, Acta Pharm. 62 (2012) 515-528.

tures with EM were then dissolved in $20 \mathrm{~mL}$ of the corresponding buffer solution of $\mathrm{pH}$ 2.0 in order to obtain solutions having about $3.0 \mathrm{mg}$ of PER per $\mathrm{mL}$ or $1.0 \mathrm{mg}$ of EM per mL. Duplicate samples were prepared and analyzed for degradation products by two HPLC methods as described in ref. 13. An HPLC instrument (1100 Series, Agilent Technologies, Germany) with a variable UV detector and column thermostat, fitted with a Hypersil ODS, 5- $\mu \mathrm{m}$ particles, $250 \times 4 \mathrm{~mm}$ i.d. column (Thermo Scientific, Waltham, USA) was used.

Stability of APIs was tested in open Petri dishes and in closed vials in a climatic chamber at $40{ }^{\circ} \mathrm{C} / 75 \% \mathrm{RH}$ in the same manner as binary mixtures.

Table II. Time of sample withdrawal for all binary mixtures with different types of MCC

\begin{tabular}{ccc}
\hline Conditions & Binary mixtures with PER & Binary mixtures with EM \\
\hline $40{ }^{\circ} \mathrm{C} / 75 \%$ RH-open & $0,4,7$ and 14 days & $0,4,7,14$ and 28 days \\
$40^{\circ} \mathrm{C} / 75 \%$ RH-closed & $0,7,14,28,56$ and 84 days & $0,14,28,56$ and 84 days \\
\hline
\end{tabular}

RESULTS AND DISCUSSION

Physicochemical properties of MCC powders that could influence drug stability in binary mixtures

Some physicochemical properties of MCC were investigated in detail according to their potential influence on the stability of API. On the basis of the MCC monograph in Ph. Eur. (4), acidity, loss on drying and particle-size as functionality-related characteristics of MCC were measured. In addition, the influence of specific surface area, energy surface properties determined by IGC $\left(\gamma_{s}^{d}, K_{\mathrm{a}}, K_{\mathrm{b}}\right)$ and water vapour sorption determined by DVS of MCC on the stability of APIs were included in the study.

The results on acidity ( $\mathrm{pH}$ of water suspension of $\mathrm{MCC}$ ), $L O D$, average particles size and specific surface area are compiled in Table III. The differences in acidity and $L O D$ between different types of MCC are small, with the exception of $L O D$ results of Avicel PH-200 LM. The results for $\mathrm{pH}$ are from 5.88 to 6.85 and for $L O D$ from 4.12 to $5.22 \%$, with the exception of LOD results of Avicel PH-200 LM (2.15\%).

The results on average particles size are in accord with the specified limits of the manufacturers. The results on specific surface area are from 0.254 to $0.903 \mathrm{~m}^{2} \mathrm{~g}^{-1}$.

The results on the dispersive component of the total surface free energy $\left(\gamma_{s}^{d}\right)$ of different types of MCC (Table III) show some differences in the nonpolar parameters of MCC (from $42.9 \mathrm{mN} \mathrm{m}^{-1}$ for Avicel PH 105 to $56.0 \mathrm{mN} \mathrm{m}^{-1}$ for Avicel PH 200). The results on $K_{\mathrm{a}}$ are from 0.086 to 0.104 and $K_{\mathrm{b}} 0.341$ to 0.558 . Higher surface energy parameters can be attributed to increased amorphicity of the sample as known from the literature on lactose or indomethacin $(22,23)$. 
T. Vehovec et al.: Influence of different types of commercially available microcrystalline cellulose on degradation of perindopril erbumine and enalapril maleate in binary mixtures, Acta Pharm. 62 (2012) 515-528.

One of the simplest means of studying the interactions of water molecules with powdered polymeric materials are moisture sorption isotherms obtained by the dynamic vapour sorption analysis (24). The results on water vapour sorption on all the measured MCCs are in good agreement with previously published results. Adsorption isotherms can be described as the type II (BET) adsorption isotherms $(25,26)$. The results on sorption, desorption and hysteresis obtained from the DVS results at $75 \%$ relative humidity (Table III) were used in the study of the influence of adsorbed water on MCC on the stability of PER and EM in mixtures with different types of MCC. Experimental conditions of $75 \% \mathrm{RH}$ were chosen in relation to $\mathrm{ICH}$ stability testing conditions of 40 ${ }^{\circ} \mathrm{C} / 75 \% \mathrm{RH}(27)$.

Table III. $p H$ of water suspension, LOD, particle size, specific surface area, IGC and DVS analysis of MCC

\begin{tabular}{lcccccccccccc}
\hline & \multicolumn{1}{c}{ IGC results } & \multicolumn{4}{c}{ DVS results at $75 \% \mathrm{RH}$} \\
\hline Type of MCC & $\mathrm{pH}^{\mathrm{d}}$ & $\begin{array}{c}\text { LOD } \\
(\%)\end{array}$ & $\begin{array}{c}\text { APS } \\
(\mu \mathrm{m})\end{array}$ & $\begin{array}{c}\text { SSA } \\
\left(\mathrm{m}^{2} \mathrm{~g}^{-1}\right)\end{array}$ & $\begin{array}{c}\gamma_{s}^{d}(\mathrm{mN} \\
\left.\mathrm{m}^{-1}\right)\end{array}$ & $K_{\mathrm{a}}$ & $K_{\mathrm{b}}$ & $\begin{array}{c}\text { Sor } \\
(\%)\end{array}$ & $\begin{array}{c}\text { Des } \\
(\%)\end{array}$ & $\begin{array}{c}\text { Hyst } \\
(\%)\end{array}$ \\
\hline Avicel PH-101 & & 6.54 & 4.55 & 73.7 & 0.567 & 50.1 & 0.094 & 0.414 & 10.40 & 13.28 & 2.88 \\
Avicel PH-101 & $\mathrm{b}$ & 6.60 & 4.42 & 74.7 & 0.596 & 50.7 & 0.094 & 0.430 & 10.38 & 13.22 & 2.84 \\
Avicel PH-101c & 6.51 & 4.64 & 71.3 & 0.549 & 50.7 & 0.092 & 0.441 & 10.03 & 12.86 & 2.83 \\
Avicel PH-102 & 6.85 & 4.74 & 112.2 & 0.790 & 47.7 & 0.086 & 0.397 & 10.16 & 12.92 & 2.77 \\
Avicel PH-105 & 6.26 & 5.06 & 26.8 & 0.903 & 42.9 & 0.069 & 0.516 & 9.97 & 12.09 & 2.12 \\
Avicel PH-112 & 6.16 & 4.14 & 110.7 & 0.543 & 46.3 & 0.085 & 0.464 & 9.52 & 12.37 & 2.85 \\
Avicel PH-200 & 6.85 & 4.12 & 173.3 & 0.412 & 54.4 & 0.095 & 0.558 & 9.52 & 12.37 & 2.85 \\
Avicel PH-200 LM & 6.34 & 2.15 & 183.3 & 0.254 & 56.0 & 0.099 & 0.453 & 10.00 & 12.66 & 2.66 \\
Microcel MC-102 & 5.99 & 4.81 & 131.6 & 0.439 & 52.0 & 0.090 & 0.527 & 9.53 & 12.30 & 2.78 \\
Microcel MC-250 & 6.28 & 4.91 & 174.7 & 0.453 & 52.7 & 0.094 & 0.534 & 9.21 & 12.10 & 2.89 \\
Microcel MC-200 & 6.19 & 5.22 & 159.9 & 0.480 & 45.5 & 0.077 & 0.341 & 9.57 & 12.16 & 2.59 \\
Vivapur 102 & 6.33 & 4.22 & 122.9 & 0.408 & 53.3 & 0.104 & 0.389 & 9.94 & 12.39 & 2.45 \\
Vivapur 101 & 6.18 & 4.32 & 72.4 & 0.507 & 48.1 & 0.092 & 0.406 & 9.87 & 12.26 & 2.39 \\
Vivapur 12 & 6.36 & 4.53 & 162.8 & 0.400 & 49.4 & 0.087 & 0.454 & 9.65 & 12.25 & 2.59 \\
Emcocel LP200 & 5.88 & 4.38 & 179.0 & 0.350 & 55.5 & 0.098 & 0.549 & 9.79 & 12.04 & 2.26 \\
\hline
\end{tabular}

a-c Different batches of the same type of MCC; $\mathrm{d}$ pH of water suspension.

$L O D$ - loss on drying, APS - average particle size, $S S A$ - specific surface area, $\gamma_{s}^{d}$ - dispersion component of surface free energy, $K_{\mathrm{a}}$ - parameter that describes the ability of the surface to act as an electron acceptor (acid number), $K_{b}$ - parameter that describes the ability of the surface to act as an electron donor (base number), Sor - sorption, Des - desorption, Hyst - hysteresis.

Stability of PER and EM alone and in binary mixtures with different types of MCC

Degradation of PER and EM in mixtures with MCC follows first-order kinetics, which is in good agreement with previously published results. The first-order degradation lines for PER and EM in a mixture with Avicel under closed and open conditions 
T. Vehovec et al:: Influence of different types of commercially available microcrystalline cellulose on degradation of perindopril erbumine and enalapril maleate in binary mixtures, Acta Pharm. 62 (2012) 515-528.

are presented in Fig. 3. The kinetic constants for degradation of PER and EM are presented in Figs. 4 and 5, for APIs alone and for all mixtures. Most correlation coefficients were above 0.9 , except for the hydrolytic degradation of PER and EM in mixtures with MCCs and the degradation of pure APIs under closed conditions. This can be explained by low degradation rates of APIs under these conditions and therefore greater influence of experimental errors.
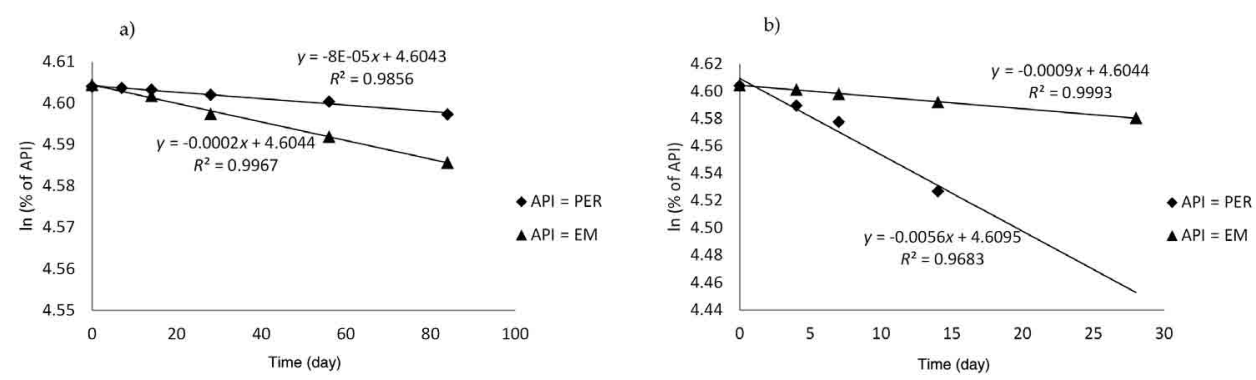

Fig. 3. First-order kinetics for degradation of PER and EM in a mixture with MCC Avicel PH-101 under: a) closed and b) open conditions. ln (\% of API) presents ratio of the amount of API at a given time point and the amount of API at the beinning of experiment.

Results of stability measurements under both conditions showed that the influence of MCC on APIs is in general destabilizing when they are in contact (Figs. 4 and 5). Under open conditions, EM in mixtures decomposed mainly into diketopiperazine, while the degradation of PER resulted in almost equal proportions of diketopiperazine and perindoprilate. Under closed conditions at $40{ }^{\circ} \mathrm{C} / 75 \% \mathrm{RH}$, both APIs in mixtures with all types of MCC decomposed mainly to diketopiperazine (Fig. 5), while a small proportion of hydrolytic degradation product and even less of other degradation products were detected. Previous studies have shown that the degree and pathway of degradation of EM depend on the acidity of the drug-excipient mixture (EM decomposes mainly into diketopiperazine when it is in contact with an excipient with acidic properties), temperature, and humidity (19). The acidic nature of MCC has been confirmed, since the main degradation product was diketopiperazine. In contrast, the good stability of EM alone was confirmed, since there was almost no degradation of API after 3 months under closed conditions (Fig. 5b), and degradation of $0.1 \%$ after 1 month under open conditions (Fig. 4b). The stability of EM alone was significantly better than the stability of EM in a mixture with MCC and the stability of PER alone and in mixtures with MCC. Interestingly, the stability of EM in a mixture with MCC was lower than that of PER in a mixture with MCC under closed conditions (Fig. 5).

Comparison of the kinetic constants for degradation showed differences in the stability of APIs when in contact with different types of MCC, but no significant differences were observed when APIs were in contact with different batches of the same MCC type.

Under open conditions at $40{ }^{\circ} \mathrm{C} / 75 \% \mathrm{RH}$, significant differences in the stability of PER and EM in binary mixtures with different types of MCC were observed (Fig. 4). The 
T. Vehovec et al.: Influence of different types of commercially available microcrystalline cellulose on degradation of perindopril erbumine and enalapril maleate in binary mixtures, Acta Pharm. 62 (2012) 515-528.

a) Kinetic constants for degradation of PER

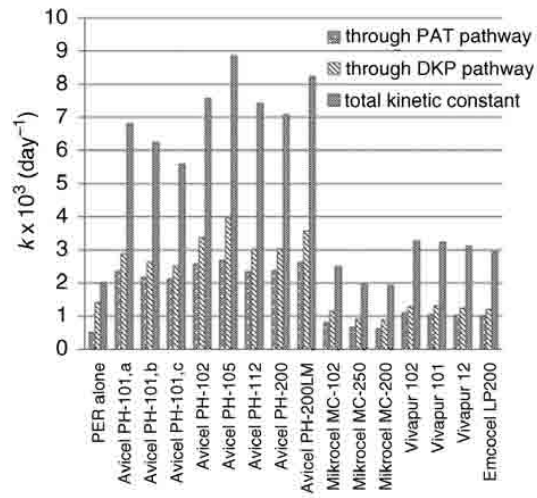

b) Kinetic constants for degradation of EM

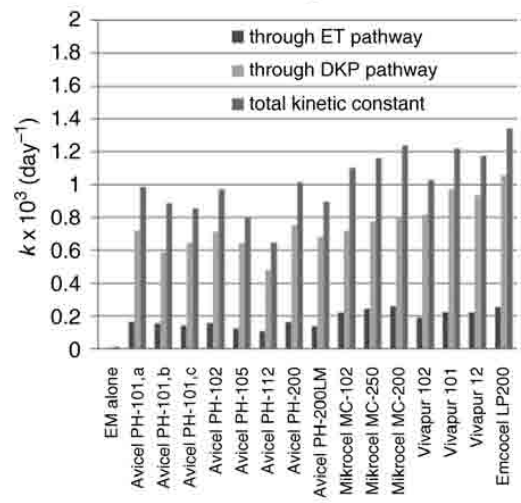

Fig. 4. First-order kinetic constants for degradation of: a) PER and b) EM determined in the stability study under open conditions at $40{ }^{\circ} \mathrm{C} / 75 \% \mathrm{RH}(\mathrm{a}, \mathrm{b}$, c: different batches of the same type of MCC).

a) Kinetic constants for degradation of PER

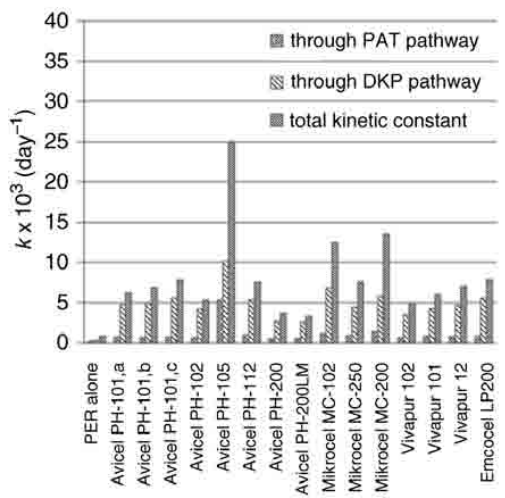

b) Kinetic constants for degradation of EM

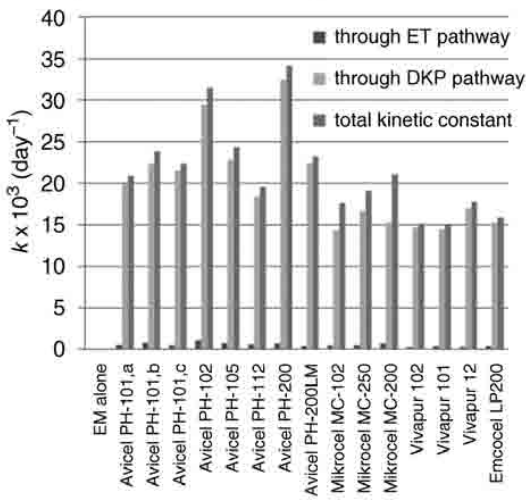

Fig. 5. First-order kinetic constants for degradation of: a) PER and b) EM determined in the stability study under closed conditions at $40{ }^{\circ} \mathrm{C} / 75 \% \mathrm{RH}(\mathrm{a}, \mathrm{b}, \mathrm{c}$ : different batches of the same type of MCC).

kinetic constants differed by a factor of 4 for PER degradation and by a factor of 2 for the degradation of EM. The highest stability was observed with MCC Microcel MC-200 for PER and with MCC Avicel PH-112 for EM. On the other hand, the lowest stability was observed with MCC Avicel PH-105 for PER and with MCC Emcocel LP200 for EM. In general, the degradation of PER was higher in mixtures with MCCs from the manufacturer FMC than from manufacturers Blanver and JRS Pharma. The situation was reversed with EM, which is most stable in a mixture with MCC from the manufacturer FMC.

Conclusions of the stability study under closed conditions differed from those obtained under open conditions. Also, under closed conditions significant differences in the stability of PER and EM in mixtures with different types of MCC were observed. The 
T. Vehovec et al.: Influence of different types of commercially available microcrystalline cellulose on degradation of perindopril erbumine and enalapril maleate in binary mixtures, Acta Pharm. 62 (2012) 515-528.

differences were larger for PER than for EM. The kinetic constants for the degradation of APIs in mixtures differed by a factor of 8 for PER and 2 for EM. PER showed the highest stability with MCC Avicel PH-200 LM and the lowest with MCC Avicel PH-105. EM showed the highest stability with MCC Vivapur 101 and the lowest with MCC Avicel PH-200.

The influence of MCC on the stability of API is complex as several parameters together are determining the stability for each API. In our stability study, the conclusions from open conditions did not reflect the results obtained under closed conditions. In stability studies, closed conditions are more relevant for the pharmaceutical development; however, the results of experiments under open conditions are obtained faster.

We expected that the stability of APIs in binary mixtures under closed conditions would depend on the particle size and surface energy of the MCC powder. MCC powder with larger particles and smaller surface area should have less influence on the stability of API than the MCC powder with smaller particles and larger surface area. The stability of APIs in a mixture could depend on the surface energy of MCC powder, since less water is available for hydrolysis in case of MCC powder with higher surface energy. In order to determine the main properties of MCC that influenced the stability of API, the results of all measured parameters of MCC ( $\mathrm{pH}$ of water suspension, loss on drying, particle size, specific surface area, water vapour sorption and surface characteristics determined by inverse gas chromatography) were correlated with the kinetic constants for degradation of both APIs. The best correlations were found if the results were divided into two groups. The first group consisted of the results of stability studies of drug mixtures (PER or EM) with MCCs from the manufacturer FRC. In the second group were the results of stability studies of drug mixtures with MCCs from manufacturers Blanver and JRS Pharma.
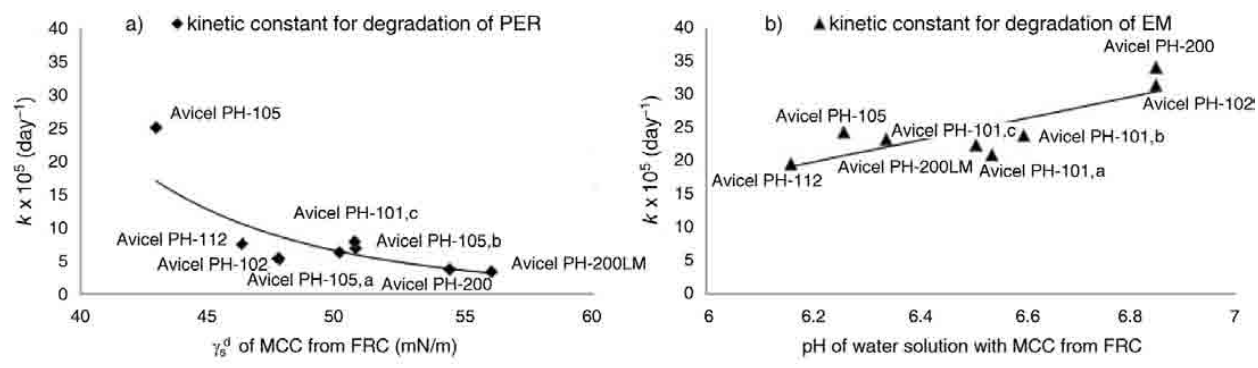

Fig. 6. Kinetic constants for degradation of: a) PER in relation to the dispersion component of surface free energy $\left(\gamma_{s}^{d}\right)$ of MCC and b) EM in relation to $\mathrm{pH}$ of water suspensions of MCC. Kinetic constants were determined in the stability study with MCCs from the manufacturer FRC under closed conditions at $40{ }^{\circ} \mathrm{C} / 75 \% \mathrm{RH}$.

Correlations from the first group indicated that the surface energy characteristics of MCCs (with PER) and acidity of MCCs (with EM) had major influence on the stability of APIs. The experimental results showed that the kinetic constants for PER degradation predominantly correlated with the results on particle size, specific surface area and IGC 
T. Vehovec et al.: Influence of different types of commercially available microcrystalline cellulose on degradation of perindopril erbumine and enalapril maleate in binary mixtures, Acta Pharm. 62 (2012) 515-528.

of MCCs (Fig. 6a). The stability was greater with MCCs, which had larger particles, lower specific surface area and higher nonpolar part of surface free energy. The highest correlation of kinetic constants degradation for EM with $\mathrm{pH}$ of water suspension of MCC was found under both stability conditions. As already proven (15), the stability of $\mathrm{EM}$ is better in an acidic environment (Fig. 6b).

Furthermore, the results in the second group indicated that under closed conditions unbound water of MCC had major influence on the stability of PER or EM in mixtures. The highest correlations of kinetic constants were found with the results on $L O D$ and results of DVS analysis. The stability of APIs was higher when less unbound water was available (Fig. 7).
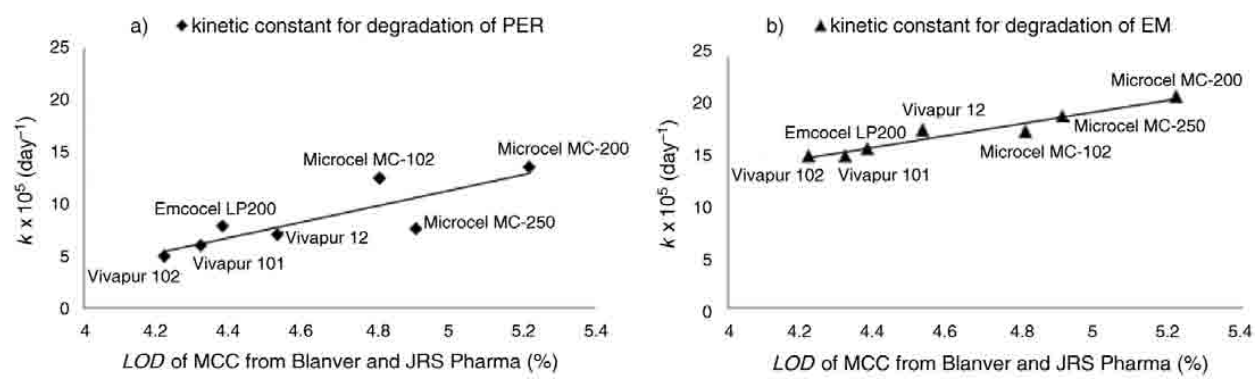

Fig. 7. Kinetic constants for degradation of: a) PER and b) EM determined in the stability study under closed conditions at $40{ }^{\circ} \mathrm{C} / 75 \% \mathrm{RH}$ in relation to $L O D$ of MCC from manufacturers Blanver and JRS Pharma.

\section{CONCLUSIONS}

This study showed differences in the stability of PER and EM when in contact with different types of MCCs that comply with the requirements of Eur. Ph. Addition of MCC to PER and EM increased the quantity of degradation products, especially the products of cyclization reaction under closed conditions. Even in case of structurally similar substances, the influence of different types of MCC on their stability is specific for each API. When excipient and API are in contact, both them determine which properties of the excipient would be dominant for the degradation of API. It is reasonable to perform stability studies of API with different types of the same excipients differing in physicochemical properties. The findings of the present study may be specifically helpful in case of very unstable APIs in contact with MCC, where the stabilization in formulation with other excipients is not satisfactory and/or the amount of MCC in formulation is very high. The stability problem could be simply solved with a different type of MCC that is also suitable for the same technological procedure.

Acknowledgements. - This work was supported by Krka d.d., Novo mesto and the Ministry of Higher Education, Science and Technology of the Republic of Slovenia. 
T. Vehovec et al.: Influence of different types of commercially available microcrystalline cellulose on degradation of perindopril erbumine and enalapril maleate in binary mixtures, Acta Pharm. 62 (2012) 515-528.

\section{REFERENCES}

1. A. H. Kibbe, Microcrystalline cellulose, in Handbook of Pharmaceutical Excipients, American pharmacists association Washington and Pharmaceutical Press, London 2000, pp. 102-106.

2. M. El-Sakhawy and M. L. Hassan, Physical and mechanical properties of microcrystalline cellulose prepared from agricultural residues, Carbohyd. Polym. 67 (2007) 1-10; DOI: 10.1016/j.carbpol.2006.04.009.

3. H. Iijima and K. Takeo, Microcrystalline Cellulose: An Overview, in Handbook of Hydrocolloids (Eds. G. O. Phillips and P. A. Williams), Woodhead Publishing Ltd., Cambridge 2000, pp. 331-346.

4. European Pharmacopoeia, $7^{\text {th }}$ ed., Council of Europe, Strasbourg 2010, pp. 1634-1637.

5. J. T. Carstensen and R. C. Lothari, Solid-state decomposition of alkoxyfuroic acids in the presence of microcrystalline cellulose, J. Pharm. Sci. 72 (1983) 1149-1154; DOI: 10.1002/jps. 260072 1010.

6. K. E. Fielden, J. M. Newton, P. O'Brien and R. C. Rowe, Thermal studies on the interaction between water and microcrystalline cellulose, J. Pharm. Pharmacol. 40 (1988) 674-678. DOI: 10. 1111/j.2042-7158.1988.tb06993.x

7. A. Mihranyan, A. Piñas Llagostera, R. Karmag, M. Strømme and R. Ek, Moisture sorption by cellulose powders of varying crystallinity, Int. J. Pharm. 269 (2004) 433-442; DOI: 10.1016/j. ijpharm.2003.09.030.

8. A. Mihranyan, S. B. Andersson and R. Ek, Sorption of nicotine to cellulose powders, Eur. J. Pharm. Sci. 22 (2004) 279-286; DOI: 10.1016/j.ejps.2004.03.012.

9. A. Mihranyan, M. Strømme and R. Ek, Influence of cellulose powder structure on moisture-induced degradation of acetylsalicylic acid, Eur. J. Pharm. Sci. 27 (2006) 220-225; DOI: 10.1016/ j.ejps.2005.10.002.

10. M. Heidarian, A. Mihranyan, M. Strømme and R. Ek, Influence of water-cellulose binding energy on stability of acetylsalicylic acid, Int. J. Pharm. 323 (2006) 139-145; DOI: j.ijpharm.2006. 05.058 .

11. Z. Simončič, P. Zupančič, R. Roškar, A. Gartner, K. Kogej and V. Kmetec, Use of microcalorimetry in determination of stability of enalapril maleate tablet formulations, Int. J. Pharm. 342 (2007) 145-151; DOI: 10.1016/j.ijpharm.2007.05.016.

12. Z. Simončič, R. Roškar, A. Gartner, K. Kogej and V. Kmetec, The use of microcalorimetry and HPLC for the determination of degradation kinetics and thermodynamic parameters of perindopril erbumine in aqueous solutions, Int. J. Pharm. 356 (2008) 200-205; DOI: 10.1016/j.ijpharm. 2008.01.031.

13. R. Roškar, Z. Simončič, A. Gartner and V. Kmetec, Stability of new potential ACE inhibitor in the aqueous solutions of different pH, J. Pharm. Biomed. Anal. 49 (2009) 295-303; DOI: 10.1016/ j.jpba.2008.11.029.

14. B. Stanizs, Evaluation of stability of enalapril maleate in solid phase, J. Pharm. Biomed. Anal. 31 (2003) 375-380; DOI: 10.1016/S0731-7085(02)00325-4.

15. B. Stanizs, Kinetics of degradation of enalapril maleate in dosage forms, Acta Pol. Pharm. 61 (2004) 415-418.

16. D. P. Ip and G. S. Brenner, Enalapril maleate, Anal. Profiles Drug Subst. 16 (1987) 207-243; DOI: 10.1016/S0099-5428(08)60557-2.

17. M. M. Al-Omari, M. K. Adbelah, A. A. Badwan and A. M. Y. Jaber, Effect of the drug-matrix on the stability of enalapril maleate in tablet formulations, J. Pharm. Biomed. Anal. 25 (2001) 893902; DOI: 10.1016/S0731-7085(01)00399-5. 
T. Vehovec et al.: Influence of different types of commercially available microcrystalline cellulose on degradation of perindopril erbumine and enalapril maleate in binary mixtures, Acta Pharm. 62 (2012) 515-528.

18. M. Frias, M. I. Sanchez de Rojas, M. P. Luxan and N. Garcia, Determination of specific surface area by the laser diffraction technique. Comparison with the blaine permeability method, $\mathrm{Ce}$ ment Cobcr. Res. 21 (1991) 709-717, DOI: 10.1016/0008-8846(91)90165-E

19. S. Baumgartner, O. Planinšek, S. Srčič and J. Kristl, Analysis of surface properties of cellulose ethers and drug release from their matrix tablets, Eur. J. Pharm. Sci. 27 (2006) 375-383; DOI: 10. 1016/j.ejps.2005.11.009.

20. V. Gutmann, The Donor-Acceptor Approach to Molecular Interactions, Plenum, New York 1978.

21. F. M. Fowkes, Quantitative characterization of the acid-base properties of solvents, polymers, and inorganic surfaces, J. Adhesion Sci. Technol. 4 (1990) 669-691; DOI: 10.1163/156856190X00595.

22. H. E. Newell and G. Buckton, Inverse gas chromatography: investigating whether the technique preferentially probes high energy sites for mixtures of crystalline and amorphous lactose, Pharm. Res. 21 (2004) 1440-1444; DOI: 10.1023/B:PHAM.0000036918.79205.4b.

23. O. Planinšek, J. Zadnik, M. Kunaver, S. Srčič and A. Godec, Structural evolution of indomethacin particles upon milling: time-resolved quantification and localization of disordered structure studied by IGC and DSC, J. Pharm. Sci. 99 (2010) 1968-1981; DOI 10.1002/jps.21986.

24. G. Zografi, M. J. Kontny, A. Y. S. Yang and G. S. Brenner, Surface area and water vapor sorption of microcrystalline cellulose, Int. J. Pharm. 18 (1984) 99-116; DOI: 10.1016/0378-5173(84)90111-X.

25. P. H. Stahl, Feuchtigkeit und Trocknen in den pharmazeutischen Technologie, UTB Steinkopff Verlag, Darmstadt 1980, pp. 20-59.

26. K. Kachrimanis, M. F. Noisternig, U. J. Griesser and S. Malamataris, Dynamic moisture sorption and desorption of standard and silicified microcrystalline cellulose, Eur. J. Pharm. Biopharm. 64 (2006) 307-315; DOI: 10.1016/j.ejpb.2006.05.019.

27. European Medicines Agency Inspections, Committee for proprietary medicinal products (CPMP), Guideline on stability testing: Stability testing of existing active substances and related finished products, London, 17 December 2003, CPMP/QWP/122/02, rev 1 corr; http://www.ema. europa.eu/docs/en_GB/document_library/Scientific_guideline/2009/09/WC500003466.pdf; last access July 9, 2012.

POVZETEK

\section{Vpliv različnih tipov komercialno dostopne mikrokristalne celuloze na razpad erbuminijevega perindoprilata in enalaprilijevega maleata $\mathrm{v}$ binarnih zmeseh}

TANJA VEHOVEC, ANDREJ GARTNER, ODON PLANINŠEK in ALEŠ OBREZA

V raziskavi smo proučevali vpliv nekaterih tipov komercialno dostopne mikrokristalne celuloze (MCC) na stabilnost izbranih zdravilnih učinkovin, kadar sta učinkovina in pomožna snov v stiku. Uporabili smo dve strukturno sorodni učinkovini, znana zaviralca angiotenzin-konvertaze, erbuminijev perindoprilat in enalaprilijev maleat. Izmerili smo najpomembnejše lastnosti mikrokristalne celuloze, ki bi lahko vplivale na stabilnost posamezne zdravilne učinkovine in določili povezavo med temi lastnostmi pomožne snovi in stabilnostjo zdravilnih učinkovin v binarnih zmeseh. Stabilnost obeh učinkovin se je razlikovala pri posameznih eksperimentih in je bila odvisna od tipa uporabljene mikrokristalne celuloze. Na stabilnost erbuminijevega perindoprilata so najbolj vplivale površinske značilnosti enega izmed proizvajalcev mikrokristalne celuloze, na stabilnost 
T. Vehovec et al.: Influence of different types of commercially available microcrystalline cellulose on degradation of perindopril erbumine and enalapril maleate in binary mixtures, Acta Pharm. 62 (2012) 515-528.

enalaprilijevega maleata pa njene šibko kisle lastnosti. V primeru ostalih dveh proizvajalcev mikrokristalne celuloze je na stabilnost obeh zdravilnih učinkovin najbolj vplivala nevezana voda.

Ključne besede: mikrokristalna celuloza, erbuminijev perindoprilat, enalaprilijev maleat, stabilnostna študija, binarna zmes zdravilna učinkovina - pomožna snov

Krka d.d. Novo mesto, Slovenija

Univerza v Ljubljani, Fakulteta za farmacijo, Ljubljana, Slovenija 